\title{
Social and Cultural Focus in EFL Learning. Does Understanding Target Language Culture Increase Interaction in the EFL Classroom?
}

\author{
Hamza Alshenqeeti \\ School of Arts and Humanities, Taibah University, \\ P.O.Box: 344, Madinah, Saudi Arabia \\ E-mail: hshenqeeti@taibahu.edu.sa
}

Received: Oct. 4, 2016 Accepted: Nov. 10, 2016 Published: December 11, 2016

doi:10.5296/ijl.v8i6.10265ＵRL: http://dx.doi.org/10.5296/ijl.v8i6.10265

\begin{abstract}
The value of encouraging interaction in the EFL classroom has been well documented in the literature and numerous methods have been indicated as being beneficial in this respect. Similarly, there is also a growing recognition of the value of incorporating social and cultural learning about the target language and its speakers into the EFL curriculum. In line with Vygotsky's view that learning is social construction that occurs when individual integrate and participate in activities and knowledge sharing, this would suggest that incorporating cultural and social learning into the language learning classroom can increase the integration of students. Drawing on definitions of culture, highlighting potential routes to providing information about target language culture and identifying the connections between cultural knowledge and language proficiency and communicative competence, the perspective is put forward that social and cultural learning can lead to increased integration in the EFL classroom.
\end{abstract}

Keywords: Communicative Competence; EFL classroom, Social and cultural learning, Socio-pragmatic language use, Target language culture 


\section{Introduction}

There is widespread recognition that encouraging English as a foreign language (EFL) students to interact during lessons supports not only motivation but also improves competence and understanding of the target language (Wu et al, 2011; Chang, 2010; Tuan and $\mathrm{Nhu}, 2010$ ). Concurrently, there is a growing recognition that combining learning about the target culture with second/foreign language learning can be beneficial in terms of communicative proficiency and ability (Byram and Feng, 2004; Blake, 2011). The reason for this is that not only does increased cultural awareness contribute to increased intercultural understanding, known as cultural competence (Jin, 2015), but the suggestion exists that increasing cultural knowledge and awareness of a target community contributes to improved communicative competence and language ability (Lazar, 2015; Leckie, 2015). Recognising the dual validity of interaction and cultural learning it is surely time to consider whether social and cultural learning can support and encourage increased interaction within the EFL classroom. In particular, examining how socio-pragmatic understanding, communicative competence and technology can be combined in the EFL classroom to enhance the relationship between cultural learning and language competency.

\subsection{Background}

The value of engaging with native speakers is well documented in the literature, and an increasing number of authors have identified that this means engagement with the target culture can be a major benefit. In this respect, Wu et al, (2011) found that students who are given the opportunity to interact not just with native speakers but also discuss English culture, were more motivated, involved and achieved improved language ability. This echoes the work of Luk and Lin, (2006) and Gilmore (2007) who also identified improved confidence, motivation and communicative ability amongst students given the opportunity to interact with native speakers and target language culture. The findings of these authors underline the importance of interaction and collaboration within the EFL classroom, even in countries where the teaching tradition is for passive learning and teacher dominance, such as China or the Middle East (Soler, 2002; Fuji et al, 2016). Furthermore, as indicated by Saeed et al, (2016) encouraging peer interaction and discussion on cultural facets of the target language appears to heighten curiosity and thus interest and engagement, which is in line with similar works by Ochoa et al, (2016). Certainly, this would appear to indicate a positive relationship between interaction and social and cultural content in the EFL classroom as noted by Ochoa et al, (2016). Given that interaction improves competence, as found by Saeed et al (2016) whose findings are echoed by those Hsieh et al, (2016). The Hsieh study was focused on 48 EFL learners who used online technology to engage with and learn English idioms, with the result that their understanding of the appropriate social usage was increased through autonomous learning and greater interaction. What these studies lead to is the perspective that if interaction improves competence, and cultural understanding has a similar effect, then there should be correlation between the two. This paper thus considers the ways that social and cultural focus and understanding can be enhanced in the EFL classroom through technology use, a focus on the target language culture and how culture and language are inter-linked. It further assesses the potential impact and benefits this may offer for increasing interaction in 
the EFL classroom, through participative learning, negotiation and co-operation between students and teachers.

\section{Literature Review}

\subsection{Classroom Interaction}

Learning itself is an integrative social activity, as recognised by Vygotskian perspectives (Vygotsky, 1978; Johnson, 2004). When individuals interact, they respond to one another and acquire knowledge through a process of sharing experience and information, through collaboration, discussion and involvement. Given this, it would suggest that a collaborative approach in the classroom would lead to a knowledge building process. In the case of the EFL classroom, Swain (2000) highlights that a collaborative approach, where there is equal input and involvement from teachers and students, encourages the activation of both social and cognitive processes which leads to increases in terms of target language use and ultimately language learning. The task-based learning approach within EFL supports this approach and recognises the values of interaction, and why it should be encouraged in the classroom (Ellis, 2003). In addition, given that learning is a social activity due to the interaction and sharing of knowledge that it requires (Jonassen and Land, 2012; Chuang et al. 2014), it would seem appropriate to suggest that EFL classrooms could use cultural and social content, to simulate a social environment that supports development and understanding. In this respect, Ellis (1990) as part of his interaction hypothesis suggests that collaborative social environments support the development and presence of negotiation, which leads to questioning and evaluation of constructs, such as cultural differences for example. The foundation of the interaction hypothesis lies in the perspective that L2 learners dealing with a communication problem will look for ways to negotiate a solution, and it is this negotiation that leads to comprehension of input. From the perspective of whether social learning increases interaction therefore, the interaction hypothesis suggests that presenting a social problem based on English culture creates a problem that the students can negotiate together to achieve a linguistic solution. By providing social and cultural cues and examples, the EFL student is motivated to explore and understand the socio-pragmatic nuances of English through knowledge of the culture, which enhances their ability to communicate effectively (Kecskes, 2015; Hinkel, 2014) This interaction hypothesis is in contrast to Krashen's input hypothesis which considers that understanding is achieved with simple input and contextual input (Mitchell et al, 2013). Certainly, there is validity in both these perspectives for language learning, but in the context of interaction and cultural learning, the value of the interaction hypothesis and its processes of negotiation and comprehension would appear to be more viable. In particular, when considering the potential contribution of cultural and social components in elevating student interaction. In the EFL classroom, whilst context is naturally important, offering learners the ability to negotiate (i.e. reach agreement through discussion), encourages greater collaboration and thus development of meta-cognitive strategies for embedding language components in the mind. It should however also be noted, as identified in a recent study by Kayi-Aydar (2013), that there can also be issues of student power balance when working in groups. The importance of these factors underline the value of ensuring collaboration in the classroom, between teacher and student and student to student 
during activities as Nicholas (2016) notes. Moreover, when there is effective collaboration, co-construction can also occur, which is particularly important when examining the potential value of social and cultural learning in enhancing classroom interaction. Co-construction, as Jacoby and Ochs, (1995:171) note is "the joint creation of a form, interpretation, stance, action, activity, identity, institution, skill, ideology, emotion or other culturally-related meaning reality". Reviewing this statement in the context of cultural and social learning components into the EFL construction, there is a potential that the approach will support the development of socially-appropriate utterances and enhanced cultural understanding. In this respect the work of Wang et al, (2013) has relevance. Wang et al's study (ibid) found that when Chinese and English students were communicating over creation and evolution of a Wiki, there was strong collaboration across and within the two language groups. Not only did the students increase their language ability, but their cooperative, collaborative approach increased the cultural understanding of both learner groups, making their language less automatised and more natural (Wang et al, 2013). In effect, the two groups were demonstrating ability and communicative competence in the socio-pragmatic use of the language forms which, as Hinkel (2014) notes, is the ultimate aim of an EFL learner. Furthermore, if interaction is increased, then there is a concurrent increase in learning opportunities (Oxford, 1997; Cao and Phillip, 2006; KaiWai-Chu and Kennedy, 2011; Lai, 2014).

Interaction in the EFL classroom comes in numerous forms such as group work, use of digital mediums and teacher led activity, as well as the more traditional teacher initiated question and answer or repetition approaches as Rido et al (2014) indicates. What should also be recognised in this regard is that interaction which provide students with increase autonomy and choice about the content and style of the interactions, there is increased interest, engagement and the potential for negotiation, collaboration, and cooperation are also increased, (Yashima et al, 2016; Peterson, 2012). From a social and cultural perspective, this indicates that the content for interactions should have cultural and social relevance as well as a reflection of students' own social reality if engagement and motivation are to occur. An approach such as this, as put forward by Kiss and Weninger (2013), recognises the importance of student input and the potential that incorporating cultural and social learning may create deviations from traditional EFL teaching. This is not necessarily negative as it encourages a more dynamic learning environment which will ultimately be more motivational for students. Incorporation of cultural and social information and knowledge should however be an element of the EFL pedagogy and not overtake the core learning of the language. Recognising this, there is a need to explore in more detail the relationship between culture and L2 learning and how the two are indelibly linked through social values, beliefs and tradition, with language acting as a form of code for the culture (Berns, 2013). This code needs to be understood if effective language skills are to be developed by EFL learners, underlining once more the importance of cultural and social learning in the EFL classroom (Weninger and Kiss, 2013).

\subsection{Culture and Language Learning}

Acquiring knowledge of target language grammar and vocabulary is fundamental to 
achieving effective outcomes in EFL studies, however if the learning environment is not rich in cultural references and there is a lack of engaging external stimuli, then learners fail to achieve a complete understanding, not just of the language but also how it reflects the culture of the target language. (Luo, 2014; Hua and Li, 2015). If there is no understanding of how language reflects the target culture, there is a greater potential for errors, social mistakes and the potential erection of communication barriers, and misunderstandings as Forman (2014) and Ahmed, (2014) note. Traditionally, the most effective way to develop this understanding was immersion in the foreign culture, but as (Shih, 2015; Lee, 2009; Boxer and Cortes-Conde, 2000), this is neither practical nor possible for every EFL student. However, with the advent of web technologies and evolutions that include virtual reality simulations the potential for virtual immersion to be incorporated in the classroom makes exposure to target culture far easier to achieve. As Yang et al (2010), these simulations now provide an enhanced potential for delivering informative, accurate and crucially interactive cultural learning in the classroom. To illustrate the value of this approach, Shih (2015) undertook a study where learners created avatars to walk through virtual reality environments, interact with native speakers and visit virtual versions of actual locations in London. A similar approach was adopted by Wang (2014) using computer simulations, and by Hsieh et al (2016) through Wiki creation. For the students in all these studies, there was a feeling of authenticity and genuine interaction with the target culture, and an improvement and enhancement of their language abilities. Clearly therefore, the utilization of technology as evidenced by Shih (2015), Wang (2014) and Hsieh et al, (2016) recognize not only the value of social and cultural components but also the role that technology can play in delivering these into the EFL classroom. Indeed, techniques such as this are also being applied in other industries to enhance and develop increased intercultural competence, underlining their value in many spheres, including EFL teaching (Mohsen, 2016; Ghadiri et al, 2016). The notion of intercultural competence is one which is of increasing importance in today's inter-connected world, and in the particular area of EFL is being seen as more and more valuable for proficiency and ability in communication skills.

\subsection{Intercultural Competence}

Byram's (1997) model of ICC (Intercultural Competence) is extensively applied in the field of EFL, with the term referring to the ability of a student (or EFL teacher) to be able to interact effectively with individuals whose cultural background is not the same as their own (Byram, 2000). Consisting of five elements related to social and cultural knowledge (knowledge of social group rites, rituals, and practices, curiosity, ability to interpret and relate cultural practices to the student's own experiences, and desire for discovery of new knowledge and cultural understanding). The final element that will allow ICC to be achieved is the ability to critically evaluate cultural and social variations but without applying negative or biased judgement if the new culture's values and practices differ substantially from one's own (Byram et al, 2001). Examining these elements in the light of simulations, it can be seen that adopting their use in the classroom can not only encourage intercultural competence, but can also elevate the level of student interaction, again underlining the relationship between social and cultural learning and interaction. 


\section{Mll Macrothink}

International Journal of Linguistics

ISSN 1948-5425

2016, Vol. 8, No. 6

Certainly, there has been a number of studies that confirm the value of have using tele collaborations during EFL lessons through the use of tools such as email, simulations, mobile device interaction with texts, and video connections with native speakers to encourage intercultural competence (Belz, 2003; Chun, 2011; Elola and Oskoz, 2008; Schuetze, 2008). These studies also indicated that in the main, the level of participation from students increased using these interactive tools, again suggesting a correlation between a focus on social and cultural understanding and EFL student interaction.

Clearly, Computer Assisted Language Learning (CALL) technologies revolutionised the way that EFL classrooms operate, and these can be extended to incorporate cultural and social facets of the curriculum (Skyes et al, 2008; Levy and Stockwell, 2013). Facebook, Twitter, YouTube and many others are now readily available to allow EFL students to view cultural practices and achieve improved social understanding of different cultures and increase their individual participation and interaction within the classroom (Skyes et al, 2008; Guth \& Helm, 2010). What is less clear however is strong evidence that it is the cultural and social learning, and not the enjoyment in using these platforms that is increasing the interaction in EFL classrooms. Although these digital solutions clearly offer ways to gain knowledge and understanding of the target language culture, there remains a potential that the students are becoming absorbed in the technology, rather than the cultural learning (Chang and Kang, 2013; Ciftci, 2016). Certainly, this immersion in technology improves attention and can lead to increases in communicative competence, although it should also be recognised that without cultural understanding there could still be gaps in understanding from a socio-pragmatic linguistic perspective as Chang and Kang (2013) identified. Given this it is also pertinent to discuss the concepts of communicative competence, culture and other terms so that their relationships and how they may be harmonised in the classroom to encourage increased interaction can be identified. In particular, the potential for novel communicative experiences that are non-linear (as with textbooks), can encourage greater adaptive abilities in terms of speaking and listening for the learners (Shimotamei and Kamijo, 2014). At the same time, the focus requires higher levels of interaction than can be founding he traditional classroom or with traditional EFL materials.

Communicative ability or communicative skill are terms that are frequently used in the EFL literature but when considering social and cultural learning as part of an EFL approach, there is a distinction between them. Abilities are a quality that an individual possesses whilst skills are more of a tool, which enable these abilities (Bradbury and Su, 2006). In the EFL context therefore, skills are knowledge of grammar and vocabulary of a language, whilst ability is the capacity to utilise these tools proficiently. For a student to achieve this, there is also a need to have within their knowledge set, the cultural, pragmatic, and social knowledge required to manage the cultural and social nuances of a language. The question then arises as to what is meant by culture and how does this manifest in language terms and social engagement?

Culture as a construct is the shared beliefs, values, practices, and language of a group or population and defines how they organise their individual and collective lives (Race, 2015). Studies in culture have identified that whilst cultures may on initial examination, appear to be diametrically opposed, when greater understanding is achieved, there is often identification of 
similarities, (Chapman, 2013). By gaining knowledge of the sociolinguistic and cultural norms which facilities integration and understanding, the ability to act and be with others in different societies is expedited (Chapman, 2013). This perspective and the notion of cultural learning as part of the EFL classroom, is in alignment with the view of Vygotsky that learning is socially constructed (Garcia, 2009). In particular, as Baker (2011) further elaborates, when there is understanding and knowledge about two cultures, this supports the creation of meaning, experiences and thus acceptance of differences, and recognition of similarities between languages and ultimately cultures. Clearly therefore, encouraging acceptance of differences highlights again the value of cultural and social learning within the EFL classroom as a tool to increase interest and thus interaction from students. The aim is to encourage a deeper understanding and knowledge of the target culture and the value of their developing language skills and cultural understanding.

It is evident from existing perspectives on interaction in the EFL classroom, and the importance of cultural understanding that EFL students are not just acquiring knowledge of a new language, but also increasing understanding of new communities, cultures and practice as Hinkel (2014) points. He further indicates that a key part of this dual learning is the important role of teachers in ensuring that students engage with the notions of cultural competence and expanded knowledge. This may have a particular salience in cultures where the teacher role is dominant and the students are passive recipients of the superior knowledge of the instructor. In these countries, there is a need to adapt and evolve from the traditional perspectives to more dynamic, collaborative, participatory lesson structure and content. The student-centred approach, which sits at the core of the task based approach to language learning offers increased opportunities for cultural and social learning and ultimately student interaction. As Yen et al (2014) highlighted, when students have tasks to undertake that are centred around use of social mediums and interaction with native speakers, their confidence, engagement and proficiency increased alongside their understanding of more pragmatic social conventions in the use of language. These findings are consistent with the view that language is a tool to share information and knowledge, develop social relationships, and provide a means of delivering cognitive expression and personal growth, as indicated by Lantolf et al (2015) but is also a socio-cultural device that can support increased knowledge of other cultures, virtually or through books/videos and direct interaction. What this means in a classroom setting is that the overall cognitive and experiential knowledge of the student is increased, leading to more expansive understanding and broader recognition and value of cultural differences. Language and learning in the EFL context ultimately becomes a means of expressing sophisticated socio-cultural interactions, co-operation, and achievement of understanding (Galantucci, 2009). When engaging in an interpersonal interaction, individuals adapt to those in the conversation through priming and mimicking (Pickering and Ferreira, 2008), and respond to perspectives, body language and the level of engagement indicated by those in the conversation (Duran and Dale, 2013). If cultural knowledge is lacking, these cues may be missed and it is therefore valuable for EFL students to learn these facets of a target language if they are to achieve the right level of competence. What this leads to is the need to understand more precisely what is meant by the term cultural learning. 
As already noted, culture is the set of knowledge, behaviours, ideas, and traditions shared by a group and passed through generations. In regards to language and cultural learning Halverson (1985) suggested that there exists "big C" and "little c" culture. The first covers the tangible aspects of culture such as food, artefacts, geography, and history, whilst the latter relates to intangible facets of a group or population such as their symbology, language, values, and behaviours (Ghadiri et al, 2015). Traditionally, there was a view that culture can be assessed as a static, classifiable, and thus teachable construct, so that students can learn facts or rules about the culture to increase their knowledge (Brooks, 1975). In more recent times, particularly with the reduction in cultural barriers that internet technology and social media platforms have created, the more pervasive view is that culture should be viewed from a dynamic perspective (Paige et al, 2003). The dynamic perspective recognises that whilst meaning is exchanged, the meanings can change dependent on actors, prior experiences and context and that the current meaning can only be determined through ongoing interaction and communication that is positive in nature. One has only to examine the different terminologies used by generations in any country to recognise the evolving nature of culture and how this is expressed to reinforce the validity of the dynamic approach (Hall, 2013). What this leads to in the context of the EFL classroom is that the social and cultural learning element should lead to positive, unbiased, accepting attitudes from students towards the target culture. Moreover, that the referents should be current, appropriate and effectively placed in the right contextual setting if understanding is to be achieved as Liu and Laohawiriyanon (2012) note. In this regard, there is a need to identify and evaluate more clearly the cultural dimensions that permeate learning in the EFL classroom.

\subsection{Cultural Dimensions of Learning in the EFL Classroom.}

Sercu (2004) suggests that foreign language learning is no longer confined to acquiring language knowledge and communication, but instead should come with a cultural dimension. The implication of this is that EFL teachers need to encourage students to learn not just the vocabulary and grammar of a language, but should also foster a curiosity and open attitude to learning about the culture on which the language is founded. This is underlined by the view of Magos and Simopoulos (2009) that intercultural competence is an ability to recognise and adapt to differences that may arise in everyday communication between different nationalities. Historically, this intercultural competence was achieved through studying abroad, travel, or meeting with native speakers at home (Fleming, 2009). Certainly, there is understanding that EFL students who travel or interact regularly with native speakers are frequently more competent communicatively than those who do not have these opportunities. Furthermore, there is evidence that where an understanding of the target culture is increased, this supports cementing of knowledge of how to adapt core learning to deliver more native like speech. This aligns with the importance of introducing a cultural dimension into the EFL classroom and the notion of intercultural communicative competence rather than achievement of full native like speech. In effect, cultural competence means that language can be used by the speaker to negotiate a range of social contexts (Byram, 2003; Corbett, 2003). However, without the cultural knowledge of social relationships in the target language this would be difficult to achieve. Again, this underlines the importance of cultural knowledge. What is less 
clear is how the teaching of cultural knowledge and achievement of cultural competence in the EFL classroom can contribute to increased interaction.

The teaching of intercultural competence is, moreover an aspect of language socialisation, again in line with Vygotskian perspectives, because the sociocultural nature of language use in English for example, will affect the pragmatic overtones of any communication exchange. This notion of language socialisation is built on the recognition that language acquisition is not distinct and separate from socialisation as it recognises that "the process of acquiring language is embedded and constitutive of the process of becoming socialized to be a competent member of a social group" (Ochs and Schieffelin, 2008). This means the language that may be used in a family unit may differ greatly from that used in schools (Blum-Kulka, 2008; Baquedano-Lopez and Kattan, 2008) and professional or academic settings. Without cultural references to apply to their language knowledge, the EFL student may struggle to achieve competence in the target language in these different settings. Similarly, pragmatic socialisation relates to being able to converse and communicate in a less formal situation, whilst academic language and literacy requires a specific type of discourse socialisation (Duff, 2010). In this regard, as Ortactepe (2012) notes, there is the notion of conceptual socialisation, which is awareness of different cultural practices that are correlated to different communication circumstances and situations. What this leads to is the view that learners need to have not just language expertise but expertise in the ways of the community with whom they are interacting as Duff (2008) notes. Again, this underlines the importance of understanding the target culture, and again the most effective way to understand a culture is to become immersed in the practices, values, and social conventions, which requires interaction. The result of this knowledge from an EFL classroom perspective therefore should be that increased focus on cultural understanding should lead to elevated levels of interaction within the EFL classroom. In tandem with this is the identity of the EFL student, how they view their own language knowledge and their interest in the target language culture in conjunction with their view of themselves as an EFL learner (Talmy, 2008; Miller, 2003; Schechter and Bayley, 2004) and as an individual with intercultural competence. The level of intercultural competence will be dependent on the individual's own desires to learn about a second culture, but also the way that it is presented in the classroom and it is this presentation again which relates to the relationship between interaction and cultural learning within the EFL classroom.

Culture, as indicated above comprises both the big and little "c" knowledge indicted by Halverson (1985). Acquisition of this knowledge and recognition of the value it can bring to communicative competence is however impacted on by the individual student's motivation to learn as this impacts on how much they engage, and interact within the learning environment. Furthermore, the different learning styles of students may also have an impact, and in this respect there are suggestions that individuals who are trusting, curious, brave, friendly and empathic are more responsive to cultural learning and engagement, than those who are not (Wu and Marek, 2013). Given this, the EFL curriculum which aims to increase interaction through incorporation of social and cultural learning must also recognise and adapt content to individual student traits and learning styles to maximise the potential value of increasing 
language proficiency and interaction through cultural awareness. In particular, as Noonan and Richards (2015) the focus should be on developing the ability to adapt the acquired language skills to different cultural and social settings.

\section{Discussion and Conclusion}

Much has been written in the past about the importance of student interaction and collaboration in the EFL classroom, and the contribution it makes to enhanced, collaborative and social learning. Similarly, the question of culturally appropriate materials has also been extensively covered in the literature. There has however been less examination of the value of incorporating information about social and cultural factors within the target language, and its potential role in increasing communicative competence, and cultural understanding. Certainly, when a student is curious about the target language culture, their interest and motivation to learn the language is increased, which suggests that incorporation of social/cultural learning could enhance classroom interaction. Through examination of the dynamic nature of both culture and language and how the latter reflects the former, particularly in terms of pragmatic inference and ability to adapt core language skills to social situations, it is it is evident that a relationship exists between these constructs. Given that language is a code that is used to navigate social situations, it would appear logical that teaching practice which provides knowledge about cultural and social facets of the target country will provide improved levels of knowledge to students about how to traverse social and other situations when interacting with native speakers. Recent studies have demonstrated the benefit of employing virtual technologies and other online sources, to provide students with opportunities to examine cultural references, and interact in simulations are more likely to discuss language problems in a collaborative and co-operative way with their peers. This encourages not only interaction but also supports develop of problem solving and negotiation approaches to language challenges. The net result is an improvement in both their communicative and intercultural competence and an increase in their interaction and social collaboration in the learning environment. It is thus the conclusion of the author that the EFL classroom and curriculum should embrace and include social and cultural references from the target culture as a standard approach. Students are more engaged and interact more freely when their curiosity about a culture is encouraged. Furthermore, they respond positively to interactions via technology that increase their need to use their language skills in a social context that reflects their own reality. The result of this is an increase in confidence, motivation and cultural understanding and provides strong evidence that social and cultural elements in an EFL classroom can support increased interaction.

\section{References}

Ahmed, S. H. A. (2015). An analysis of textbooks series based on English as international language. International Journal of Research Studies in Language Learning, 5(1), 99-103.

Baker, C. (2011). Foundations of Bilingual Education and Bilingualism (5 $5^{\text {th }}$ Ed.). Clevedon: Multilingual Matters.

Baquedano-Lopez, P., \& Kattan, S. (2008). Language Socialisation in Schools. In Duff, P.A., 


\section{Macrothink}

International Journal of Linguistics

ISSN 1948-5425

2016, Vol. 8, No. 6

\& Hornberger, N. H. (Eds), Encyclopedia of Language and Education (2nd Ed.), Vol. 8, Boston, MA: Springer.

Belz, J. A. (2003). Linguistic perspective on the development of intercultural competence in telecollaboration. Language Learning \& Technology, 7(2), 68-99.

Berns, M. (2013). Contexts of competence: Social and cultural considerations in communicative language teaching. Berlin: Springer Science \& Business Media.

Blake, R. J. (2011). Current trends in online language learning. Annual Review of Applied Linguistics, 31, 19-35.

Blum-Kulka, S. (2008). Language Socialisation and Family Dinnertime Discourse, in Duff, P.A., \& Hornberger, N.H. (Eds.), Encyclopedia of Language and Education (2 ${ }^{\text {nd }}$ Ed.), Vol. 8, Boston, MA: Springer.

Boxer, D., \& Cortés-Conde, F. (2000). Identity and ideology: Culture and pragmatics in content-based ESL. Second and foreign language learning through classroom interaction, (pp.203-219).

Bradberry, T. R., \& Su, L. D. (2006). Ability-versus skill-based assessment of emotional intelligence. Psicothema, 18(Suplemento), 59-66.

Byram, M. (1997). Teaching and Assessing Intercultural Communicative Competence, Clevedon, UK: Multi-Lingual Matters.

Byram, M. (2000). Assessing Intercultural Competence in Language Teaching, Sprogforum, $18(6), 8-13$.

Byram, M. (2003). On being "Bicultural" and "Intercultural", In: Alred, G., Bryam, M. and Fleming, M., (Eds.). Intercultural Experience and Education, UK: Cromwell, (pp. 50-67).

Byram, M., \& Feng, A. (2004). Culture and language learning: teaching, research and scholarship. Language teaching, 37(3), 149-168.

Byram, M., Nichols, A., \& Stevens, D. (Eds.). (2001). Developing Intercultural Competence in Practice, Clevedon, UK: Multi-Lingual Matters.

Cao, Y., \& Philp, J. (2006). Interactional context and willingness to communicate: A comparison of behavior in whole class, group and dyadic interaction. System, 34(4), 480-493.

Chang, H. J., \& Kang, M. K. (2013). YouTube video clips as a stimulus for culture-based English reading for EFL learners. STEM Journal, 14, 153-171.

Chang, L. Y. H. (2010). Group processes and EFL learners' motivation: A study of group dynamics in EFL classrooms. TESOL Quarterly, 129-154.

Chapman, A. (2013). Language Learning in Europe. Alibaba Languages.

Chuang, M. T., Chang, B., \& Chen, H. C. (2014). Investigating reported social and affective strategy use by EFL learners in virtual and real learning environments. International Journal 
of Applied Linguistics and English Literature, 3(2), 27-33.

Chun, D. M. (2011). Developing intercultural communicative competence through online exchanges. CALICO Journal, 28(2), 392-419.

Çiftçi, E. Y. (2016). A Review of Research on Intercultural Learning through Computer-Based Digital Technologies. Journal of Educational Technology \& Society, 19(2), 313-327.

Corbett, J. (2003). An Intercultural Approach to English Language Teaching, Great Britain: Multi-Lingual Matters.

Duff, P. A. (2010). Language Socialisation Into Academic Discourse Communities, Annual Review of Applied Linguistics, 30, 169-192.

Duff, P. A. (2008), Introduction to Volume: Language Socialisation. In Duff, P. A., \& Hornberger, N. H. (Eds.). Encyclopedia of Language and Education, Vol. 8 ( $2^{\text {nd }}$ ed.), Boston, MA: Springer.

Duran, N. D., \& Dale, R. (2013). Perspective-taking in dialogue as self-organization under social constraints. New Ideas in Psychology.

Ellis, R. (2003). Task-based language learning and teaching. Oxford: Oxford University Press.

Ellis. R. (1990). Instructed Second Language Acquisition. Oxford: Basil Blackwell.

Elola, I. and Oskoz, A. (2008). Blogging: Fostering intercultural competence development in foreign language and study abroad context. Foreign Langauge Annals, 41(3), 454-474.

Fleming, M. (2009). Introduction. In Feng, A., Byram, M., \& Fleming, M., (Eds.), Becoming Interculturally Competent through Education and Training, Bristol, UK: Multi-Lingual Matters, 1-15.

Forman, R. (2014). How local teachers respond to the culture and language of a global English as a foreign language textbook. Language, Culture and Curriculum, 27(1), 72-88.

Fujii, A., Ziegler, N., \& Mackey, A. (2016). Peer interaction and metacognitive instruction in the EFL classroom. Peer Interaction and Second Language Learning: Pedagogical potential and research agenda, 45, 63.

Galantucci, B. (2009). Experimental Semiotics: A New Approach for Studying Communication as a Form of Joint Action, Topics in Cognitive Science, 1(2), 393-410.

García, O. (2009). Chapter 8 "Education, multilingualism and translanguaging in the $21^{\text {st }}$ century". In Mohanty, A.K., Panda, M., Phillipson, R., \& Skutnabb-Kangas, T. (Eds.) ,Multilingual education for social justice: globalising the local. New Delhi: Orient Black Swan.

Ghadiri, M., Tavakoli, M., \& Ketabi, S. (2015). Introducing culturally-adaptive English language pedagogy (CELP): Integrating critical cultural awareness through the 'little-c' 
culture in Iran's EFL curriculum. International Journal of Society, Culture \& Language, 3(2), 115-124.

Gilmore, A. (2007). Authentic materials and authenticity in foreign language learning. Language teaching, 40(2), 97-118.

Guth, S., \& Helm, F. (2010). Telecollaboration 2.0: Language, literacies and intercultural learning in the $21^{\text {st }}$ century. Bern, Switzerland: Peter Lang.

Hall, J. K. (2013). Teaching and researching: Language and culture. Oxon: Routledge.

Halverson, R. J. (1985). Culture and Vocabulary Acquisition: A Proposal, Foreign Language Annals, 18(4), 327-332

Hinkel, E. (2014). Culture and pragmatics in language teaching and learning. Teaching English as a second or foreign language, 4, 39.

Hua, C., \& Li, B. (2015). Bringing fun and meaning into grammar learning: A case study of a secondary-level EFL class in Hong Kong. Cogent Education, 2(1), 111-139.

Jacoby, S., \& Ochs. S. (1995). Co-construction: An Introduction. Research on Language and Social Interaction, 28, 171-183.

Jin, S. (2015). Action Research Using Facebook To Promote Korean EFL Learners' Intercultural Competence. About Language Learning and Technology, (P.38).

Johnson, M. (2000). Interaction in Oral Proficiency Interview: Problems of Validity. Pragmatics, 10(2), 215-231.

Jonassen, D., \& Land, S. (Eds.). (2012). Theoretical foundations of learning environments. Oxon: Routledge.

Kai-Wai Chu, S., \& Kennedy, D. M. (2011). Using online collaborative tools for groups to co-construct knowledge. Online Information Review, 35(4), 581-597.

Kayi-Aydar, H. (2013). Scaffolding language learning in an academic ESL classroom. ELT Journal, 67(3), 324-335.

Kecskes, I. (2015). How does pragmatic competence develop in bilinguals?. International Journal of Multilingualism, 12(4), 419-434.

Kiss, T., \& Weninger, C. (2013). A semiotic exploration of cultural potential in EFL textbooks. Malaysian Journal of ELT Research, 9(1), 19-28.

Krashen, S. (1992). The Input Hypothesis: An Update.”. Linguistics and language pedagogy: The state of the art (pp. 409-431).

Lai, H. Y. T. (2014). Learning English as an International Language: EFL Learners' Perceptions of Cultural Knowledge Acquisition in the English Classroom. Asian Social Science, 10(1), 1.

Lantolf, J. P., Thorne, S. L., \& Poehner, M. E. (2015). Sociocultural theory and second 
language development. Theories in second language acquisition: An introduction, (pp.207-226).

Lázár, I. (2015). EFL learners' intercultural competence development in an international web collaboration project. The Language Learning Journal, 43(2), 208-221.

Leckie, F. (2016). Students' Perspectives on Extensive Literature: Using Literature to Enhance Communicative Competence and Cultural Understanding in the EFL Classroom. [Online] available: http://www.diva-portal.org/smash/get/diva2:905879/FULLTEXT01.pdf, [accessed 01.11.2016]

Lee, J. F. (2009). ESL student teachers' perceptions of a short-term overseas immersion programme. Teaching and Teacher Education, 25(8), 1095-1104.

Levy, M., \& Stockwell, G. (2013). CALL dimensions: Options and issues in computer-assisted language learning. Oxon: Routledge.

Liu, S., \& Laohawiriyanon, C. (2012). Cultural content in EFL listening and speaking textbooks for Chinese university students. International Journal of English Language Education, 1(1), 68-93.

Luk, J., \& Lin, A. M. (2006). Classroom Interactions as Cross-Cultural Encounters: Native Speakers in EFL Lessons. New Jersey: Lawrence Erlbaum Associates.

Luo, J. J. (2014). Using popular culture to promote learning in EFL classrooms: A case study. Procedia-Social and Behavioral Sciences, 112, 209-218.

Magos, K., \& Simopoulos, G. (2009). “Do you know Naomi?” Researching the intercultural competence of teachers who teach Greek as a second language in immigrant classes, Intercultural Education, 20(3), 255-265

Miller, J. (2003). Audible Difference: ESL and Social Identify in Schools, Clevedon, UK: Cromwell Press

Mitchell, R., Myles, F., \& Marsden, E. (2013). Second language learning theories. Oxon: Routledge.

Mohsen, M. A. (2016). The Use of Computer-Based Simulation to Aid Comprehension and Incidental Vocabulary Learning. Journal of Educational Computing Research.

Nicholas, A. (2016). Developmentally sensitive assistance and development: collaboration between Japanese EFL learners. Pedagogies: An International Journal, 11(1), 22-42.

Nunan, D., \& Richards, J.C. (Eds.) (2015). Language learning beyond the classroom. Oxon: Routledge.

Ochoa, C., Cabrera, P., Quiñónez, A., Castillo, L., \& González, P. (2016). The Effect of Communicative Activities on EFL Learners' Motivation: A Case of Students in the Amazon Region of Ecuador. Colombian Applied Linguistics Journal, 18(2), 39-48.

Ochs, E., \& Schieffelin, B. B. (2008). Language Socialisation: A Historical Overview. In 
Duff, P. A., \& Hornberger, N. H., (Eds.), Encyclopedia of Language and Education ( $2^{\text {nd }}$ Ed), Vol. 8, Boston, MA: Springer.

Ortactepe, D. (2012). The Development of Conceptual Socialisation in International Students: A Language Socialisation Perspective on Conceptual Fluency and Social Identity, Newcastle Upon Tyne, UK: Cambridge Scholarly

Oxford, R. L. (1997). Cooperative learning, collaborative learning, and interaction: Three communicative strands in the language classroom. The Modern Language Journal, 81(4), 443-456.

Paige, R. M., Jorstad, H. L., Siaya, L., Klein, F., \& Colby, J. (2003). Culture Learning in Language Education: A Review of the Literature in Lange, D. L., \& Paige, R. M. (Eds.). Culture As The Core: Perspectives on Culture in Second Language Learning, Greenwich: CT: Information Age Publishing (pp. 173-236).

Peterson, M. (2012). EFL learner collaborative interaction in Second Life. ReCALL, 24(01), 20-39.

Pickering, M. J., \& Ferreira, V. S. (2008), Structural priming: A critical review. Psychological Bulletin, 134(3), 427-459.

Race, R. (2015). Multiculturalism and Education. London: Bloomsbury Academic.

Rido, A., Ibrahim, N., \& Nambiar, R.M. (2014). Investigating EFL Master Teacher's Classroom Interaction Strategies: A Case Study in Indonesian Secondary Vocational School. Procedia-Social and Behavioral Sciences, 118, 420-424.

Saeed, K. M., Khaksari, M., Eng, L. S., \& Ghani, A. M. A. (2016). The Role of Learner-Learner Interaction in the Development of Speaking Skills. Theory and Practice in Language Studies, 6(2), 235-251.

Schechter, S., \& Bayley, R. (2004). Language Socialisation in Theory and Practice, International Journal of Qualitative Studies in Education, 17(5), 605-625.

Schuetze, U. (2008). Exchanging second language messages online: Developing an intercultural communicative competence. Foreign Langauge Annals, 41(4), 660-672.

Sercu, L. (2006). The Foreign Language and Intercultural Competence Teacher: The Acquistion of a New Professional Identity, Intercultural Education, 17(1), 55-72.

Shih, Y. C. (2015). A Virtual Walk Through London: Culture Learning Through a Cultural Immersion Experience, Computer Assisted Language Learning, 28(5), 407-428.

Soler, E. A. (2002). Relationship between teacher-led versus learners' interaction and the development of pragmatics in the EFL classroom. International Journal of Educational Research, 37(3), 359-377.

Swain, M. (2000). The Output Hypothesis and Beyond: Mediating Acquisition through Collaborative Dialogue. Sociocultural Theory and Second Language Learning, edited by 
James P. Landtolf. Oxford: Oxford University Press.

Sykes, J. M., Oskoz, A., \& Thorne, S. M. (2008). Web 2.0, synthetic immersive environments, and mobile resources for language education. Calico Journal, 25(3), 528-546.

Talmy, S. (2008). The Cultural Productions of the ESL Student At Tradewinds High: Contingency, Multi-directionality and Identity in L2 Socialisation, Applied Linguistics, 29(4), 619-644.

Tuan, L. T., \& Nhu, N.T.K., (2010). Theoretical review on oral interaction in EFL classrooms. Studies in literature and language, 1(4), 29-41.

Vygotsky, L. S. (1978). Mind in Society: The Development of Higher Psychological Process. Cambridge: Harvard University Press.

Wang, J., Zou, B., Wang, D., \& Xing, M., (2013). Students' perception of a wiki platform and the impact of wiki engagement on intercultural communication. System, 41(2), 245-256.

Wu, P.H.N. and Marek, M.W. (2013). Helping second language literature learners overcome e-learning difficulties: LET-NET team teaching with online peer interaction. Journal of Education and Learning, 2(4), 87-101.

Wu, W. C. V., Yen, L. L., \& Marek, M. (2011). Using Online EFL Interaction to Increase Confidence, Motivation, and Ability. Educational Technology \& Society, 14(3), 118-129.

Yang, J. C., Chen, C. H., \& Jeng, M. C. (2010). Integrating video-capture virtual reality technology into a physically interactive learning environment for English learning. Computers \& Education, 55(3), 1346-1356.

Yashima, T., Ikeda, M., \& Nakahira, S. (2016). Talk and Silence in an EFL Classroom: Interplay of Learners and Context. In The Dynamic Interplay between Context and the Language Learner (pp. 104-126). Palgrave Macmillan UK.

Yen, Y. C., Hou, H. T., \& Chang, K. E. (2015). Applying role-playing strategy to enhance learners' writing and speaking skills in EFL courses using Facebook and Skype as learning tools: a case study in Taiwan. Computer Assisted Language Learning, 28(5), 383-406.

\section{Copyright Disclaimer}

Copyright for this article is retained by the author(s), with first publication rights granted to the journal.

This is an open-access article distributed under the terms and conditions of the Creative Commons Attribution license (http://creativecommons.org/licenses/by/3.0/). 